\title{
The effects of primary school quality on the educational participation and attainment of Kenyan girls and boys
}

Cynthia B. Lloyd

Population Council

Barbara Mensch

Population Council

Wesley H. Clark

Population Council

Follow this and additional works at: https://knowledgecommons.popcouncil.org/departments_sbsr-pgy

Part of the Demography, Population, and Ecology Commons, Family, Life Course, and Society Commons, Gender Equity in Education Commons, and the International Public Health Commons How does access to this work benefit you? Let us know!

\section{Recommended Citation}

Lloyd, Cynthia B., Barbara Mensch, and Wesley H. Clark. 1998. "The effects of primary school quality on the educational participation and attainment of Kenyan girls and boys," Policy Research Division Working Paper no. 116. New York: Population Council. 


\section{The Effects of Primary School $Q$ uality on the Educational Participation and Attainment of Kenyan Girls and Boys}

Cynthia B. Lloyd

Barbara S. Mensch

Wesley H . Clark 


\title{
The Effects of Primary School Quality on the Educational Participation and Attainment of Kenyan Girls and Boys
}

\author{
Cynthia B. Lloyd \\ Barbara S. Mensch \\ Wesley H. Clark
}

Cynthia B. Lloyd is Senior Associate and Director of Social Science Research, Policy Research Division, Population Council. Barbara S. Mensch is Associate, Policy Research Division, Population Council. Wesley H. Clark is Data Management Analyst, Policy Research Division, Population Council.

The authors gratefully acknowledge the role of all of their collaborators on the field research study: Ayo Ajayi, Cecilia Ndeti, Karin Hyde, and Annabel Erulkar. They would also like to acknowledge helpful sampling advice provided by Ian Diamond and helpful statistical advice provided by Roger Vaughn, Mark Montgomery, and Mary Arends-Kuenning, and comments by Sajeda Amin and T. Paul Schultz. Funding for this research study was provided by a research grant from NICHD as well as from a USAID Cooperative Agreement with the Population Council. Donors who supported the field research include the Ford Foundation, USAID, the Wallace Global Fund, the Compton Foundation, and UNFPA-Nairobi. This paper was originally presented at the annual meeting of the Population Association of America, 2-4 April 1998, Chicago. 


\begin{abstract}
In Kenya, adolescent girls fare poorly relative to boys in an educational system characterized by enormous growth, deteriorating quality, and rising costs. Girls are more likely than boys to drop out of school prematurely and are less likely to do well on the primary school leaving exams that come at the end of grade eight. Using data from nearly 600 adolescents aged 12-19 in combination with data collected from 36 primary schools in which those adolescents are enrolled, this paper investigates the effect of school quality on the likelihood of dropping out from primary school in three districts of Kenya. In particular, various elements of schools that are either different for girls and boys or that have a potentially different effect for boys than for girls are explored. The results document both the power of existing gender systems at the level of the family and the potential power of gender systems within the school environment. Although the determination as to whether girls will remain in school rests largely in the hands of the family, school factors also appear to matter. Schools in which boys are favored in class, in which boys are provided with a more supportive environment in terms of advice, in which teachers take the importance of hard subjects such as math less seriously for girls, in which boys are left free to harass girls, and in which girls' experience of unequal treatment is not recognized by boys, discourage girls' retention.
\end{abstract}

This material may not be reproduced in any form without written permission from the authors. 
Few studies of education in developing-country settings have examined the impact of school quality on enrolment and retention. Not only is it critical to determine what school factors affect enrollment and retention generally, it is also important to determine which matter for girls and which for boys. Sex differences in school enrollment often emerge during the teenage years, suggesting the possibility that school quality may have a gender dimension. The same school environment may be experienced differently by boys and girls because of differences in curricular opportunities within the school; differences in treatment by individual teachers; and differences in rules, regulations, and administrative practices. Moreover, even if the school environment is the same for both boys and girls, gender differences may occur in the impact of particular aspects of that environment on school retention. Our interest in studying school quality in Kenya is motivated by these concerns.

It is well accepted in the literature that school quality matters for the development of cognitive competencies and ultimate earnings. However, despite the many empirical studies that have attempted to identify which school inputs lead to greater school effectiveness, little consensus exists about which are critical. Much of the controversy in the literature relates to the question of the proper estimation of effects. As statistical approaches become more sophisticated, however, it becomes increasingly clear that the importance of specific types of schooling inputs may vary depending on the context. Indeed, at an early phase of educational development, school effectiveness may depend more heavily on factors that encourage attendance and retention because, without initial enrollment and steady attendance to a basic level, children do not have sufficient exposure to achieve even the minimal cognitive goals set out in most national education plans for basic schooling. At a later phase of educational development, when almost all children complete basic schooling, gains in standardized test scores per grade attended become more important as measures of school effectiveness. Thus, in developing countries where enrollment is not yet universal or where repetition 
rates and dropout rates are substantial before primary school completion, an approach to measuring school quality that is limited to factors affecting the test scores of students who remain in school will be missing an important part of the story. That few studies of school quality have looked at school factors that are potentially relevant to enrollment and retention is surprising, given the importance accorded to schooling in the development and population literatures. For example, the achievement of primary schooling has been associated not only with large economic returns but also with many social returns, including, in the case of girls, lower fertility, lower infant and child mortality, better child health and education, reductions in gender inequality within the family, and later ages of marriage.

Although Kenya has achieved near-universal enrollment in primary school, girls' enrollment begins to fall off by comparison with that of boys as they enter their teenage years. In more developed parts of the country, the gender gap is most noticeable in the transition from primary to secondary school. In lessdeveloped parts of the country, the gender gap emerges during the last years of primary school. In either case, the quality of the primary schools may be critical. Girls pass through puberty and become adolescents during their primary school years. They become particularly vulnerable at that point within the school system because of widely held negative attitudes about adolescent girls. At this age, a supportive learning environment for girls could make a critical difference in school retention.

The Kenyan data presented here were collected specifically to address the question posed by this paper: What are the effects of school quality on the educational participation and attainment of Kenyan girls and boys? Through purposeful sampling of three districts (Kilifi, Nakuru, and Nyeri), the study was designed to maximize the range of school quality observed in Kenya. By combining a community-based survey of both in- and out-of-school adolescents in 19 sam- 
pling clusters in the three districts with school visits to the main primary schools attended by adolescents in those clusters, school characteristics can be linked to all the adolescents currently or formerly attending each of the sample schools.

This paper begins with the development of a conceptual framework for the measurement of school quality, whereby quality is defined to encompass those aspects of primary school that enable and support parents and students to complete the primary level and continue to the secondary level. This framework is applied to the Kenyan case, with an exploration of the salient dimensions of school quality as measured in our situation analysis of schools. Data on educational participation and attainment by sex, age, and district provide a background for the presentation of the multivariate results. Here the focus is particularly on gender differences and on those aspects of schooling that are ultimately important to educational outcomes but that are less related than others to test scores.

\section{DIMENSIONS OF SCHOOL QUALITY: A CONCEPTUAL FRAMEWORK}

Much research on the determinants of school enrollment, retention, and ultimate grade attainment in developing countries has been confined to an exploration of the role of individual and family factors (see, for example, Lloyd and Blanc 1996; Hill and King 1993; Sathar and Lloyd 1994; Lloyd and Gage-Brandon 1994; Jamison and Lockheed 1987; Chernichovsky 1985, among many others), often with particular attention given to the ways in which these factors may operate differently for boys and for girls. Although for some time school quality has been recognized as potentially important to these outcomes (see Behrman and Birdsall 1983), data constraints have made identifying the specific dimensions of school quality that matter difficult. To date, two types of approaches have been taken in order to assess the importance of school quality for enrollment, retention, and ultimate grade attainment. In the first approach, crude ag- 
gregate measures for school quality are developed at the level of the sample community, the administrative district, or the country, such as distance to school as a measure of the availability or accessibility of schools (see, for example, Sathar and Lloyd 1994) or resources per student, teacher credentials, and student-teacher ratios (Lloyd and Gage-Brandon 1994; Lee and Barro 1997). In these studies, "quality" is uniformly statistically significant when introduced into a regression analysis of the determinants of individual educational outcomes. In the second approach, latent school-quality variables are derived by regressing individual standardized test scores on various explanatory factors at the individual and family level and a set of dummy variables to represent each of the schools attended by students in the sample. These latent quality variables, which are based on the coefficients of each of the school dummy variables, are then introduced into regressions estimating the determinants of enrollment, dropout, or attainment (Khandker et al. 1994; Hanushek and Lavy 1994). This indirect but more comprehensive approach to the estimation of school-quality effects has also found the effects of quality to be consistently statistically significant. Thus, in studies setting out to analyze the determinants of enrollment, retention, and attainment, school quality has never been measured directly, nor has any attempt been made to identify empirically the critical elements of quality that matter. This shortcoming can be explained partly by the data available for this type of analysis, which are primarily derived from household surveys, and lack direct detailed information on schools.

On the other hand, school-effectiveness studies have gone a long way toward identifying the key dimensions of the educational production process that have potential implications for the development of cognitive competencies (Lockheed et al. 1991) and in measuring their statistical impact on performance in various types of standardized tests. ${ }^{1}$ Such studies, which necessarily must confine themselves to students who are enrolled in school, have mainly measured 
the direct effects of school quality on student achievement and largely neglected the indirect effects that operate through school quality on entry, retention, and ultimate grade attainment (with the partial but notable exception of Glewwe and Jacoby 1994). These approaches are, therefore, better suited to measuring school effectiveness in settings where the age of school entry is uniform, where enrollment is near universal, and where attrition between grades is relatively minor. In many poor countries of the world, particularly in Africa, these conditions do not apply. Indeed, in such settings some of the most important potential effects of investments in school quality may come through their implications for school entry, enrollment, and retention. (For further discussion of this point, see Lloyd and Mensch [1998].)

From a review of the school-effectiveness literature, three broad elements of the educational process are found that have been identified as contributing to positive outcomes on various types of standardized tests: (1) time to learn, such as the hours school is in session and the time spent in the classroom; (2) material inputs, such as classrooms, books, desks, and libraries; and (3) effective teaching, such as pedagogical practices and teachers' competence. Certainly, we would expect some of these elements to be important not only to academic achievement but also to retention in school in that students who benefit from them and perform well will be encouraged to continue. Surely parents' perceptions of a school's quality may be important in the initial decision as to whether or not they enroll their children (see Bommier and Lambert [1997] for some empirical documentation of this point for Tanzania). Other elements in addition to those mentioned above might be important in encouraging the continued attendance of the middling and lower-ranked students once they have been enrolled. Teachers' attitudes may be critical, particularly for girls, who are typically socialized from a young age to expect a future of second-class citizenship within the family as well as narrowly circumscribed opportunities for economically productive roles out- 
side the family. For this reason, an expansion of the traditional framework for school quality is proposed here to encompass a variety of dimensions of school policy, classroom dynamics, and teachers' attitudes that may be important to the overall atmosphere of the school and the amount of encouragement students, particularly girls, receive.

The framework, as it has been distilled from the school-effectiveness literature and the authors' earlier work (Mensch and Lloyd 1998), is presented in Table 1. Under the heading time to learn, are included not only the total time the school is in session over the academic year but also various factors that can reduce the actual time for learning below what is allowed by the school calendar, such as unscheduled closures due to weather, natural disasters, political disruptions, v£!chers' absences, and time taken during the day for students' nonacademic activities such as chores or duties and punishments. The time to learn dimension of school quality is defined in entirely quantitative terms and provides the temporal dimension within which the other elements of material inputs and school and classroom dynamics can operate.

The traditional list of material inputs includes facilities, instructional materials, and teaching staff. Under facilities, not only are infrastructure and equipment included but also amenities such as toilets, electricity, and water that, while not necessary for learning to take place, may have profound implications for the comfort of students and, therefore, the effectiveness of the school. Textbooks have been singled out in the literature as the most essential of instructional materials, but to what extent they are provided by the school or they must be purchased by the family is not always clear. Although the publication and distribution of textbooks is usually organized at the national level by the Ministry of Education, schools are not always responsible for their distribution. Sometimes they are only available commercially through bookshops, in which case parents are responsible for their purchase. 


\section{Time to learn}

Total time school in session over school year

Time lost to unscheduled closures

Time lost to teachers' absences

Time lost due to discipline/punishment ${ }^{\mathrm{a}}$

Time lost to students' extracurricular duties

\section{Material inputs}

\section{Facilities}

Infrastructure: buildings, classrooms, sports facilities, a science labs, library

Equipment: desks, backboards, telephone, duplicating equipment

Amenities: toilets, ${ }^{\text {a }}$ electricity, water

Instructional materials: textbooks, maps and charts, lab equipment, sports equipment, ${ }^{\mathrm{a}}$ library books

Teaching staff:

Quantity: student-teacher ratio, sex ratio ${ }^{\mathrm{a}}$

Quality: training, supervision, experience, workload, remuneration

Curriculum beyond core ${ }^{\text {a: }}$ sports, art, music, drama, clubs, family life education

Other staff: supervisors, student advisor, nurse or doctor

Community support

\section{School and classroom dynamics}

General school environment: orderliness and organization (vandalism, class schedule disruption, enforcement of uniforms)

Classroom dynamics

Use of instructional time

Language spoken

Students' participation ${ }^{\mathrm{a}}$

Teachers' treatment of students ${ }^{\mathrm{a}}$

Classes streamed by ability

School head's and teachers' attitudes towarda:

Teaching boys versus teaching girls

Girls' and boys' abilities/importance and ease of subjects for each

Teaching family planning/sexuality

Schoolgirl pregnancy/sex with teachers

School policies/practices with gender implications ${ }^{\text {a }}$ : separate classes, separate curricula, different types of duties, discrimination in rewards, pregnancy tests; family life education instruction

Interaction outside classroom ${ }^{\mathrm{a}}$ :

Student-to-student

Teacher-to-student

${ }^{a}$ There is a possible gender difference for these items. 
The usual list of material inputs is expanded to include curriculum beyond the core, such as sports, the arts, and more practical types of education that teach skills for living such as family life education, as well as the presence of nonacademic staff such as student advisors and a nurse or a doctor. Although these other inputs have not been as directly linked with learning, they are, nonetheless, related to dimensions of education that are potentially valuable, and they may be important to enrollment and retention. A successful transition to adulthood is one in which a young person is allowed to grow to develop her or his full potential physically, intellectually, and emotionally before taking on adult roles. School has much to contribute to the full development of human capabilities beyond the acquisition of academic knowledge and skills. Education has consumption as well as investment value as Sen (1997) asserts in explaining his preference for the concept of human capability rather than the more familiar concept of human capital. Investments in human capability not only enhance individuals' productive capacity but their ability to "lead freer and more fulfilling lives" (Sen 1997: 1,960).

Under the heading of school and classroom dynamics are included various aspects of the school and classroom environment beyond pedagogical practices. The orderliness and organization of the school are potentially important to overall school performance. In addition to the use of instruction time and language spoken, we would expect that the extent of student participation, the quality of teacher-student interactions (in terms of encouragement or discouragement), and the way in which classes are grouped (randomly or by ability) will all affect the quality of the classroom experience as well as the effectiveness of the teacher in imparting knowledge and developing skills. Underlying teachers' behaviors in the classroom are attitudes about gender that have important implications for girls. These attitudes relate to boys' and girls' innate abilities, their "teachability," and their sexuality, and may be reflected in school policies and administrative practices that treat boys and girls differently. To date, the authors are aware of 
only one empirical study conducted in Kenya attempting to measure the effect of teachers' attitudes on school outcomes, but the analysis was restricted to the determinants of exam scores and did not explore effects on enrollment and grade attainment (Appleton 1995).

An element of school quality could have a gender dimension either because it is differentially available within a school to boys and girls or because, while uniformly available, it has a potentially different effect on boys and girls. Thus, girls and boys may experience the same school differently. If systematic differences exist within a school between boys and girls in the time devoted to their duties and punishments, then boys and girls cannot be assumed to have the same time to learn. Furthermore, if such differences exist, they could have additional discouraging effects on girls that go beyond the simple difference in time they have in which to learn because of the gender messages embodied in such practices. If sports facilities or equipment are lacking for girls, they will have less opportunity to develop physical skills and experience teamwork and at the same time will receive clear messages about appropriate gender roles. The quality of teacher-student interactions is another dimension of the school experience that may differ for boys and girls. Sadker and Sadker (1995) have documented all the subtle ways in which girls may receive discouraging messages from teachers in the classrooms through hundreds of hours of observation in US classrooms.

Other elements of the school environment may be shared by boys and girls but nonetheless have differential implications for girls. For example, limited or poor-quality toilet facilities may have differential implications for girls because of their special needs during their menstrual periods as well as their vulnerability to sexual harassment on their way to or from the toilet. The sex ratio of teachers is another dimension of material inputs that might be more important for girls given the potential importance of female professional role models in a genderstratified society to their encouragement and success. All cases where a potential 
gender dimension is hypothesized, either because it is differentially available or because it might have a differential effect, are indicated in Table 1.

\section{DIMENSIONS OF SCHOOL QUALITY: THE KENYAN CASE}

To explore the relationship between school quality and the educational participation and attainment of adolescent boys and girls, a small-scale field study in rural areas of three districts in Kenya (Kilifi, Nakuru, and Nyeri) was conducted in May-August 1996 consisting of both household and school visits. A purposeful sampling strategy was used to select the widest range of school environments within the limits of the sample size so that some representation of the very best and the very worst examples would be included along with the more typical school situations in Kenya. The sampling strategy was designed in three stages. The first stage involved the selection of three of Kenya's 50 districts representing the range of school environments not just from the point of view of national examination results but also in terms of the participation of girls in school. Using district rankings on the 1993 Kenyan Certificate of Primary Education (KCPE) scores as well as primary and secondary enrollment rates for boys and girls, Nyeri was selected as reflecting the high end, Nakuru the middle, and Kilifi as the low end of the schooling spectrum. The second stage was to select 12 urban and rural clusters within each district (in geographically proximate groups of three to four clusters) from the national sampling frame again to reflect the high, middle, and low end of the educational spectrum within each district, as measured by KCPE scores. The third stage was to select specific clusters and schools from preliminary household listings undertaken before the main survey was conducted so as to maximize the overlap of primary schools and potential adolescent respondents within each cluster. ${ }^{2}$ At this stage, the urban clusters had to be dropped because too many schools were represented within each cluster for the limited field budget. The result was a sample drawn from 19 rural clusters, 
seven each in Nyeri and Nakuru and five in Kilifi, which included 36 primary schools, 10 in Kilifi and 13 each in Nakuru and Nyeri. Overall, 76 percent of the adolescents in the household survey had attended or were currently attending one of the 36 schools in the school sample (see Ajayi et al. [1997] for further details).

\section{A Situation Analysis of Schools}

Situation analysis - a research methodology developed by the Population Council to provide an accurate description of the functioning of family planning services through on-site visits to a large number of service-delivery points-has been adapted for this study to the description of the school environment. Although many school-based surveys have been conducted in developing countries that have collected data for school-effectiveness studies (for example, Appleton [1995]; Glewwe et al. [1995]; Glewwe and Jacoby [1994]; Tan et al. [1997]; Lockheed and Longford [1989]; Khandker et al. [1994], among many others), few have been as exhaustive as the situation analysis in Kenya (notable exceptions are the school studies of Jamaica by Glewwe et al. [1995], and of Botswana by Fuller et al. [1994], and of Fuller and Snyder [1991]) or have the potential to explore the effects of school characteristics on enrollment and attainment through a linked community-based survey. Furthermore, none has given systematic attention to the gender-specific elements of school quality. ${ }^{3}$

Primary school in Kenya consists of eight grades, or standards. Because enrollment in primary school is nearly universal in Kenya, ${ }^{4}$ the assessment of primary school quality here was focused on the last two years of the primary school cycle (standards 7 and 8), where dropping out begins to emerge as a problem. Thus, in addition to an interview with the head teacher and the observation of school facilities in each of the 36 primary schools in the sample, the situation analysis of each school includes the observation of four English and four math classes for standards 7 and 8 (two per teacher), interviews with the four English 
and math teachers who were observed, and a self-administered questionnaire with a random sample of 30 boys and 30 girls enrolled in standards 7 and 8 . Each school was visited by a three-person team for two to three days. The data, which were collected via both observation and interview, provide a description of the quality of schooling in both quantitative and qualitative terms. Although this paper focuses on the results that can be quantified, the qualitative materials, including transcripts of the supervisors' field notes and the notes of the classroom observers were essential to the overall research design and critical to the development of hypotheses and the interpretation of results. For further details, see Mensch and Lloyd (1998).

\section{Key Dimensions of Variability in School Quality in Kenya}

Applying the conceptual framework developed in Table 1, the school survey instruments were designed to measure quantitatively each of the elements described, often using multiple approaches. For example, not only was the head teacher asked for a report on teachers' absences but also students were asked whether any of their teachers had been absent in the last week. Not only was the state of the toilets observed and assessed but also girls were asked whether they had stayed home from school during menstruation. Students were asked whether they had been harassed and were observed in hallways to see if they were harassed. Students were asked whether they had all their textbooks and were observed to see whether they had the required math or English text in the classes that were studied. Teachers were queried concerning their attitudes about teaching boys and girls, and their behavior toward boys and girls was observed by counting the number of encouraging or positive interactions (or "good events") per class period ${ }^{5}$ and by asking students their perceptions of their experiences.

After a detailed review of all the quantitative data collected, which produced a total of 272 school variables, those variables were discarded that (1) 
were based on questions that were, as seen in retrospect, poorly framed or worded and, therefore, not clearly understood by respondents; (2) were unlikely to have been reliably reported as a result of courtesy bias (for example, if teachers' absences were frequently reported by students but rarely by the head of school, the students' reports were accepted); (3) were likely to be endogenous with respect to the outcome variable such as class size or teacher-student ratio, given that schools with more dropouts tend to have smaller classes in standards 7 and 8 as a result of attrition; or (4) showed no variation across schools. Although factors with minimal variation across schools in Kenya may be important elements of school quality, no means in this setting are available to verify their importance empirically, and thus they could not be used. For example, some studies have found that the availability of desks for each student are important. In Kenya, almost all students in the sample of schools have desks, regardless of the school they attend, so this dimension of school quality is not explored further. Other examples may exist of school factors that are systematically absent, such as science labs or school nurses and, therefore, their importance cannot be assessed in this setting. After this initial culling, 76 variables (11 time-to-learn factors, 36 material-input factors, and 29 school-and-classroom-dynamics factors) remained.

Factor analysis was used to explore whether several variables collected to represent one element of the framework could be combined. Few cases were found where variables could be combined, confirming the complexity of schooling and its multiple dimensions. One example where the development of an index was possible was for facilities and equipment, where a variable was constructed that combines information on nine of the original dimensions of school resources. Table 2 presents a list of the remaining 43 variables representing school quality according to the framework presented in Table 1, showing means, standard deviations, and correlations with a commonly used proxy for school quality - the average KCPE score for each school in the previous year's round of 
Time to learn

Total time school in session over school year

\section{Days per year}

Hours per day

\section{$\overline{\mathbf{x}}$} KCPE score

Time lost due to teachers' absences

Students not reporting a teacher absent last week (\%)

Time lost to discipline/punishment

Students not reporting punishment last school day (\%)

Boy/girl difference in students not reporting punishment last school day (\%)

$\begin{array}{rrr}207.1 & 19.5 & 0.19 \\ 7.4 & 1.9 & 0.32 \\ 43.1 & 22.8 & 0.41 \\ 79.7 & 17.3 & 0.27 \\ -1.2 & 12.6 & -0.15\end{array}$

\section{Material inputs}

Facilities

Total school fees (100s KSh) ${ }^{\mathrm{a}}$

19.1

15.0

0.42

Facilities index (standardized) ${ }^{\mathrm{b}}$

$-0.4$

0.5

0.39

Instructional materials

Average percent of students present in class

with required text

11.1

$-0.25$

Boy/girl difference of students present in class

who had required text $(\%)$

Teaching staff

Sex of head teacher $($ female $=1)$

$-6.3$

12.7

0.22

Teachers sex ratio, (M/F)

0.1

1.7

0.2

0.28

Teacher credentials ( $\%$ KSCE)

84.8

1.9

$-0.08$

20.6

10.2

0.09

Teachers with in-service training in past two years $(\%)^{c}$

13.1

18.7

$-0.11$

Average number of years teaching, any level

30.5

5.3

0.15

Teacher workload (average hours per week)

Supervision scale (0-2) for teachers observed/ given feedback

7.1

$-0.20$

Curriculum beyond core

Number of family life education subjects taught (0-3)

Other staff

Students reporting presence of advisers (\%)

Boy/girl difference in students reporting presence

of advisers (\%)

\section{School and classroom dynamics}

General school environment

Observed classes on time/full length (\%)

43.0

20.0

$-0.15$

Classroom dynamics

Class time not used for copying/correcting (\%) $\quad 97.5$

73.0

3.4

$-0.08$

Class time not used for exercises (\%)

58.6

11.3

$-0.13$

Classes where only English spoken (\%)

28.9

27.6

$-0.22$

Average number of "good" events per standardized class

Boy/girl difference in average number of

"good" events per standardized class

1.6

14.2

$-0.13$

4.6

0.24 
Correlation

\begin{tabular}{llll} 
Variable & $\bar{X}$ & $\begin{array}{c}\text { Standard } \\
\text { deviation }\end{array}$ & $\begin{array}{c}\text { with } \\
\text { KCPE score }\end{array}$ \\
\hline
\end{tabular}

Average total events that are "good" per

standardized class (\%)

87.9

6.1

0.24

Boy/girl difference in total events that are

"good" in standardized class (\%)

$-1.5$

7.3

$-0.03$

Students who do not say teachers discourage them (\%)

84.9

13.2

0.22

Boy/girl difference in students who say teachers

do not discourage them (\%)

Students who say sexes are treated equally (\%)

Boy/girl difference in students who say sexes are

treated equally (\%)

Students who performed special duties yesterday (\%)

Classes streamed by ability (yes $=1$ )

1.0

17.9

$-0.07$

86.4

8.2

0.01

$-0.8$

15.5

0.03

9.0

5.0

$-0.10$

0.1

0.3

0.24

School head's and teachers' attitudes toward

Teachers who do not express a preference

for teaching boys (\%)

Teachers who think math is important for girls (\%)

Head teachers who approve of teaching sexuality

and/or family planning in primary school (scale, $0-2$ )

Teachers who say there should be a severe response

to teachers having sex with students $(\%)^{\mathrm{c}}$

80.8

21.8

0.14

67.8

23.0

0.16

Teachers who say a girl should be able to resume school after childbirth $(\%)^{\mathrm{c}}$

$$
1.2
$$$$
0.8
$$$$
-0.28
$$

53.8

30.3

Head teacher who says there should be a severe response to teachers having sex with students $(1=$ yes)

95.7

9.4

$-0.28$

Head teacher who says a girl should be allowed to

resume school after childbirth (1= yes)

Interaction outside classroom

Students who have been pressured for sex at school (\%)

Average of 8 possible questions on harassment

( 4 boys, 4 girls) in which no harassment reported $(\%)^{\mathrm{c}}$

Boy/girl difference in average of 4 possible questions on harassment in which no harassment was reported ${ }^{\mathrm{d}}$

$\begin{array}{rrr}0.8 & 0.4 & -0.15 \\ 0.9 & 0.3 & -0.06 \\ 12.4 & 11.1 & -0.21 \\ 79.8 & 12.5 & 0.31 \\ 14.2 & 7.2 & -0.10\end{array}$

$\mathrm{KCPE}=$ Kenyan Certificate of Primary Education. KSCE = Kenyan Certificate of Secondary Education.

${ }^{\mathrm{a}} 100 \mathrm{KSh}=$ approximately US $\$ 20$. ${ }^{\mathrm{b}}$ The facilities index is composed of nine variables measuring presence at school of a telephone, typewriter, and duplicating machine in the office; presence of water; percentage of teachers in observed classes with a desk; absence of cracks/holes in walls; number of toilets per student; number of playing fields per student; and presence of electricity in any classroom. Because the metrics of these variables differ, they were first standardized with a mean of 0 and a standard deviation of 1 before combining them. Although the scale itself is not interpretable and can take on a negative value, in comparing schools, a lower score means that a school is less well equipped. ${ }^{\mathrm{c}}$ Percent includes head teachers who teach. ${ }^{\mathrm{d}}$ The harassment questions ask about boys and girls teasing and hitting/tripping/blocking students of the opposite sex. Four questions are asked of boys and four of girls. Students of both sexes are asked about boys harassing girls and girls harassing boys. Each question has three possible responses: $0=$ no; $1=$ occasionally; and $2=$ often. The harassment variable indicates the percentage of the maximum possible harassment score $($ maximum $=8)$ that could have been reported but was not. Thus, if every student in a school reported that teasing and hitting/ tripping/blocking of both sexes occurred often, the school would score 0 . 
national exams - across the sample of 36 primary schools. Some of these variables characterize a school factor that is shared by boys and girls, and some of these variables measure differences between boys and girls in their experiences within the same school. The latter variables are applicable to mixed schools only. Each shared variable has been defined in such a way that a greater value would reflect higher quality either in terms of more time to learn, more resources, better pedagogical practices, or a more supportive environment for girls. Each of the gender-difference variables is calculated as the value of the boys' variables minus the value of the girls' variables.

We can see from Table 2 that, on average in Kenya, the school day is long (more than seven hours), and school is in session for 207 days in the year. Teachers' absence is a fairly common occurrence (on average 57 percent of students reported that a teacher was absent in the previous week), and at least 20 percent of students were punished on average in the last school day (with a great deal of variation across schools). Indeed, the field supervisors commented that, because of teachers' absences, classes were often rescheduled, doubled up, or taught by other teachers. They noted also that particular schools "were run by the cane" (Mensch and Lloyd 1998).

Resources available per student as measured by total fees or by the facilities index are highly variable. Fewer than 50 percent of students on average had their required text on the day of observation in class. Most head teachers are male (only two schools in our sample of 36 had female head teachers), and the majority of teachers are also male (with an average male/female ratio of 1.7 to 1). Most teachers have the minimum credential of the Kenyan Certificate of Secondary Education, but only 21 percent on average have received in-service training in the last two years. Average teaching experience among the teachers in the sample schools is more than 13 years per teacher, but a great deal of variability is found in teachers' average years of experience from school to school. Teachers put in an 
average of more than 30 hours a week in teaching and nonteaching duties, and most teachers have received some supervision in the form of classroom observation in the last year. Out of three important family life education subjects-puberty, sexual biology, and STDs-no more than one is taught per school on average, a result that is consistent with students' very low level of knowledge of reproductive physiology (see Mensch and Lloyd [1998]). Most students (more than 80 percent) report that there is someone in the school from whom they can seek advice if they need to.

More than half of observed classes (57 percent) started late or were shorter than scheduled, and the field supervisors' often commented about general disorganization and frequent absence of the head teacher (Mensch and Lloyd 1998). Copying and correcting exercises did not consume much class time, a good sign from a pedagogical point of view. Few classes were grouped into sections by ability. Although teaching is supposed to be conducted entirely in English after standard 4 , in roughly 40 percent of classes observed, the teacher used some language other than English in the course of the class period. As defined above, roughly 29 "good" events in terms of teacher-student interaction occurred during a standardized class (of 40 minutes' duration with 20 students of each sex), but the incidence of "good" events varied widely across schools. Furthermore, of the total, most events or interactions that occurred in a class were evaluated as "good." Few students report being discouraged by their teachers, and most report that boys and girls are treated equally.

Whereas 20 percent of teachers express an explicit preference for teaching boys (versus no preference or a preference for teaching girls), 32 percent on average do not think math is an "important" subject for girls to study. Teachers often used adjectives such as "weak," "lazy," and "blind" to characterize the girls in their classrooms (Mensch and Lloyd 1998). Although almost all teachers think that girls should be allowed to resume their education after giving birth to a child, 
only a slight majority feel that the response against a teacher who has had sex with a student should be "severe" (that is, dismissal, charged in court, or made to marry the girl). Head teachers' attitudes on this point are more consistently "severe." 6

The gender-difference variables, which compare the experience of boys and girls with respect to the incidence of punishment, the possession of required texts, the availability of someone at school from whom they can seek advice, the number of "good" teacher-student interactions, the extent to which they perceive that boys and girls receive equal treatment, and the extent of various types of harassment, are highly variable across schools and therefore, characterizing the typical experience is difficult.

The most striking finding in Table 2 is the low correlation between any of these variables and the average KCPE score for each school-a commonly used proxy of school quality among researchers and a direct measure used by Kenyan parents. Of the 43 variables measuring school quality presented in Table 2, more than 50 percent (23) are negatively associated with the KCPE score. Among the remaining correlations, only three approach 0.4 - total school fees, the facilities index, and the proportion of students not reporting a teacher's absence last week. This finding is important in that it points to the complexity of school quality and the inadequacy of any one proxy to measure its various effects.

\section{GENDER DIFFERENCES IN SCHOOL PARTICIPATION}

\section{AND ATTAINMENT IN KENYA}

\section{School Enrollment in the Three Districts}

Data from the preliminary household listing of 12 clusters in each district provide some background on overall enrollment rates and on gender differences across the three districts. Table 3 indicates that school attendance among adolescents varies within Kenya by location and age and in two of the three districts by 
Table 3 Percent of adolescents currently attending school by age, sex, and district, Kenya, 1996

\begin{tabular}{|c|c|c|c|c|c|c|}
\hline \multirow[b]{2}{*}{ District } & \multicolumn{2}{|c|}{$12-14$} & \multicolumn{2}{|c|}{$15-16$} & \multicolumn{2}{|c|}{ 17-18 } \\
\hline & Male & Female & Male & Female & Male & Female \\
\hline Nyeri $(\mathrm{N}=699)$ & 95 & 94 & 80 & 80 & 57 & 60 \\
\hline Nakuru $(\mathrm{N}=909)$ & 90 & 90 & 72 & 77 & 60 & 52 \\
\hline Kilifi $(N=1,237)$ & 83 & 71 & 74 & 55 & 47 & 29 \\
\hline
\end{tabular}

Note: Results are based on a preliminary household listing. Reprinted from Mensch and Lloyd (1997).

sex. Although the majority of adolescents are currently in school, attendance drops off substantially according to age through the teenage years. In addition, in Kilifi, adolescent girls are much less likely to be in school than are boys, especially in the older age groups; less than one-third of girls aged 17-18 still attend school, compared with nearly one-half of boys.

The other noteworthy finding is that most older adolescents who are still in school attend primary school even though the expected age for primary school leaving is 14 (see Table 4). For this reason, this study focuses on primary schools

Table 4 Percent of schoolgoing adolescents currently attending primary school by age and district, Kenya, 1996

\begin{tabular}{lcccc}
\hline District & $\mathbf{1 2 - 1 4}$ & $\mathbf{1 5 - 1 6}$ & $\mathbf{1 7 - 1 8}$ & Total \\
\hline Nyeri $(\mathrm{N}=571)$ & 96 & 73 & 35 & 79 \\
Nakuru $(\mathrm{N}=710)$ & 98 & 71 & 41 & 81 \\
Kilifi $(\mathrm{N}=791)$ & 99 & 90 & 80 & 94 \\
\hline
\end{tabular}

Note: Results are based on a preliminary household listing. Reprinted from Mensch and Lloyd (1997). 
because they best capture the school experience of the majority of schoolgoing adolescents in Kenya. Table 4 also reveals considerable differentials by district, with the vast majority of schoolgoing 17-18-year-olds in Kilifi attending primary school, compared with about one-third of their counterparts in Nyeri.

\section{Adolescent Survey}

The sample consists of 774 adolescents aged 12-19 (247 in Kilifi, 293 in Nakuru, and 234 in Nyeri). In each of the 19 clusters, all households with a resident adolescent were identified for interview. In households with more than one adolescent, one was randomly preselected for interview from the preliminary household listings. For each adolescent, a parent or responsible adult was also interviewed. From these interviews, information was gathered on the family background and educational history of each adolescent, as was much other relevant data on maturation, sexual experience, pregnancy, marriage, childbearing, contraceptive use, reproductive health, drug and alcohol use, and delinquency, as well as attitudinal data relevant to all of these topics. Further details about sampling and about the survey can be found in Ajayi et al. (1997).

\section{Outcome Variables}

For the statistical analysis, the outcome variable chosen is the hazard of dropping out by year since first school entry. ${ }^{7}$ In Figure 1, proportions leaving school are given from year at first entry for each of the three districts, based on a life-table analysis. In Kilifi, dropouts begin to emerge in the fourth year of school, and the gender gap widens steadily until ten years after school entry. In Nakuru, whereas dropouts begin to occur after four years of school and rise slowly until eight years of school, dropouts rise dramatically for girls after eight years and the gender gap opens up. In Nyeri, few students drop out before their sixth year in school; dropouts rise steadily after that and the gender gap widens. 

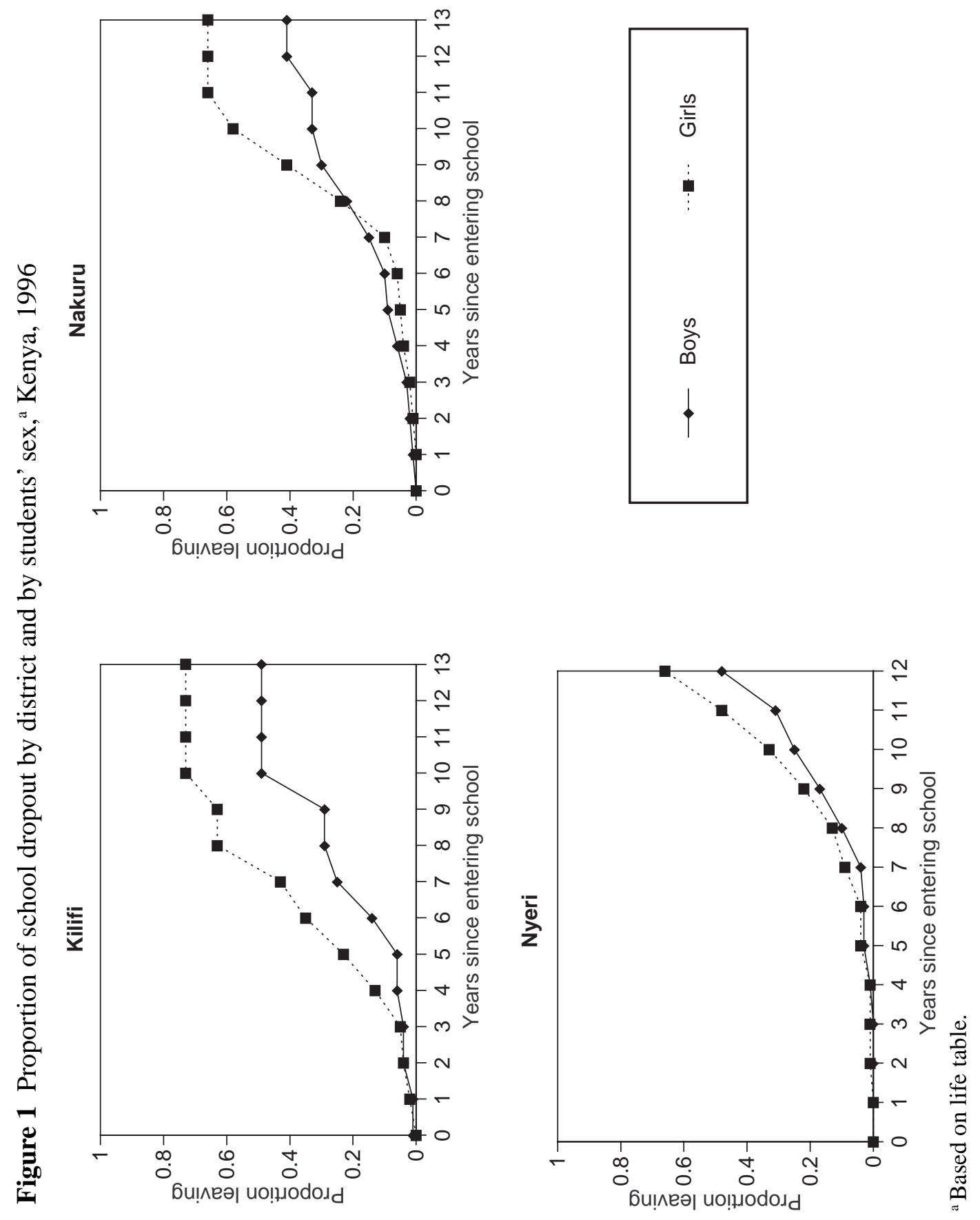


\section{Multivariate Results}

A proper analysis of the effects of school quality on dropout rates requires a longitudinal design in which effects of school quality as measured in Period 1 are observed in Period 2 through a follow-up of students enrolled in Period 1 to learn about those who remained in school and those who dropped out. Such an approach, although expensive and time consuming, is ultimately necessary if the hypotheses developed have to be tested thoroughly. Given the exploratory nature of this research, the cross-sectional approach is a necessary first step in what the authors hope will be a new line of research on schooling that broadens the traditional production-function approach to include additional school outcomes and new school characteristics. To link school quality, as measured at the time of the survey, to dropouts that occurred at various times in the past, school quality, as measured by the various dimensions included in the analysis, must be assumed not to have changed over time. However, little evidence is available to support such an assumption.

\section{Statistical Issues}

The range of school choice in Kenya presents us with an analytical challenge; we cannot assume that school quality is exogenous, given the potential choices clearly available to parents. If parents or their children select schools for certain attributes, it is not possible to conclude that a statistical association between that attribute and the probability of dropout is causal. If we think of the schools selected by parents residing in a particular cluster as the set available within that community, the choice appears startlingly large in the Kenyan context. Table 5 shows by cluster (which the Kenya Central Bureau of Statistics defines as a geographic grouping of approximately 100 proximate households) ${ }^{8}$ the number of adolescents in the sample, the number of primary schools named by these adolescents (as their current or last-attended primary school), and the 
Table 5 Number of adolescents, schools attended by adolescents, and schools visited per cluster, Kenya, 1996

\begin{tabular}{|c|c|c|c|}
\hline Cluster \# & $\begin{array}{l}\text { Adolescents } \\
\text { per cluster }^{\text {a }}\end{array}$ & $\begin{array}{c}\text { Number of } \\
\text { different primary } \\
\text { schools attended } \\
\text { by adolescents } \\
\text { in each cluster } \\
\end{array}$ & $\begin{array}{c}\text { Number of primary } \\
\text { schools visited } \\
\text { per cluster }\end{array}$ \\
\hline 133 & 38 & 9 & 2 \\
\hline 134 & 40 & 16 & 2 \\
\hline 142 & 28 & 5 & 2 \\
\hline 144 & 25 & 5 & 2 \\
\hline 147 & 29 & 2 & 1 \\
\hline 148 & 23 & 8 & 2 \\
\hline 149 & 49 & 6 & 2 \\
\hline 158 & 39 & 7 & 2 \\
\hline 163 & 62 & 6 & 1 \\
\hline 164 & 62 & 11 & 4 \\
\hline 167 & 58 & 12 & 2 \\
\hline 176 & 27 & 3 & 1 \\
\hline 705 & 38 & 11 & 2 \\
\hline 707 & 39 & 6 & 2 \\
\hline 708 & 51 & 17 & 2 \\
\hline 712 & 58 & 10 & 4 \\
\hline 723 & 32 & 8 & 2 \\
\hline 724 & 22 & 6 & 1 \\
\hline 728 & 53 & 13 & 2 \\
\hline Total & 773 & 140 & 36 \\
\hline
\end{tabular}

${ }^{a}$ The cluster number is missing for one adolescent. ${ }^{b}$ Adolescents living in several neighboring clusters may attend the same school, so that the total number of schools represented in the sample is less than the sum of schools in the column.

number of schools in the sample. The number of primary schools ranges from two to 16 in a cluster, and these clusters are rural, which makes the results all the 
more striking. Although these data are likely to exaggerate the range of school choice for some of the older adolescents who have already left or completed primary schools in other geographic locations, because of the possibility of families' migration into the cluster, clearly considerable school choice exists in Kenya.

Because of the importance of KCPE scores in progression from primary to secondary school in Kenya (in public secondary schools places are available for only about the top 40 percent of those sitting for the KCPE exam each year), parents are most likely to assess school quality primarily on the basis of how students in those schools perform each year on the KCPE. Schools are ranked each year within each district from high to low on KCPE scores, and the results are published in the local newspapers. Furthermore, schools with particularly sharp rises or declines in their scores are noted. However, parents may be less likely to give other school attributes of potential importance to this analysis as much weight in school-choice decisions, partly because they are less likely to have information about such attributes and partly because of the overriding importance of KCPE scores to students' successful progression to secondary school. As discussed above and shown in Table 2, almost none of the school attributes included within the model of school quality is highly correlated with KCPE scores (indeed, for more than 50 percent of the variables, the correlations are perverse), and yet many may be of potential importance for school retention. Variables that relate to gender differences are particularly notable in this regard. In subsequent analysis, the authors plan to try to address the issue of school choice statistically by collecting some basic information on each of the schools that were not included in the original sample of 36 . In the meanwhile, the reader should be alerted that the effects of some elements of school quality - those most highly correlated with KCPE scores — on the probability of dropout may be estimated here with bias.

Another methodological problem concerned the potential selectivity of the adolescent sample. Although 76 percent of our adolescent sample were attending 
or had attended one of the 36 schools in our sample, the remaining 24 percent were attending or had last attended another 104 primary schools. In some cases, adolescents may have moved with their families into the district for non-schoolrelated reasons after they had attended a primary school elsewhere. In other cases, parents may have chosen to send their child to another nearby school or even a school out of the cluster (a boarding school or one near family members with whom the student could live). Without information on these other schools, the analysis of the effects of school quality had to be confined to the sample of adolescents whose schools were visited.

To address the selectivity issue, the characteristics of adolescents whose schools are among the 36 visited are compared with the characteristics of students for whom school characteristics are not currently available. Table 6 shows only one important difference between adolescents selected for the analysis and those that are not - the latter are roughly one year older. The older the adolescent, the more likely her/his family has moved away from the area in which her or his primary school was located. Because the background characteristics of selected and excluded adolescents (particularly parents' educational background and household possessions index ${ }^{9}$ ) are so similar, the selectivity issue need not be addressed further in the statistical analysis.

\section{Statistical Model}

The initial plan for the analysis of the data involved a fixed-effects model in which a dummy variable for each of the 36 schools would be introduced into a hazard model of the probability of dropout along with the usual individual and family determinants of the probability of dropout. The coefficients of the dummies for each of the 36 schools could then be used as a latent index of "quality" that could be further decomposed through a cross-school analysis of the various potential determinants of that index. This sort of analysis could not be under- 
Table 6 Characteristics of adolescents who have ever attended school according to whether they have primary school match, Kenya, 1996

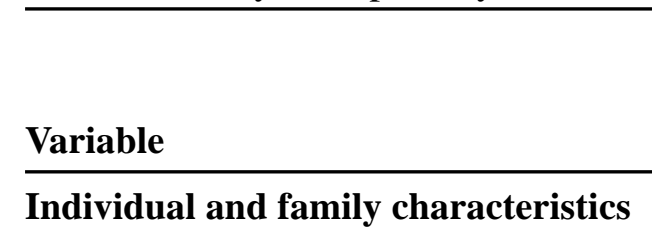

Female (omitted $=$ male)

Attended

Attended

sample

unsampled

school

school

Difference

Age

0.48

0.54

NS

Entry age

14.8

15.8

$* *$

Bottom quartile class rank ${ }^{\mathbf{a}}$

(omitted = top 3 quartiles)

7.1

7.0

NS

Christian (omitted $=$ Muslim, other)

0.32

0.38

NS

Kikuyu/Kalenjin (omitted $=$ other)

0.86

0.84

NS

District $($ omitted $=$ Kilifi $)$

Nakuru

0.64

0.61

NS

Nyeri

0.37

0.40

NS

0.30

0.30

NS

Parents married $($ omitted $=$ no $)$

Yes

0.76

0.73

NS

Missing

0.04

0.02

*

Mother's education (omitted $=<$ primary)

Primary completion

0.31

0.31

NS

Secondary completion

0.14

0.13

NS

Missing

0.21

0.22

NS

Female household head

(omitted $=$ male head)

0.36

0.29

$+$

Number of same-mother siblings

5.1

5.1

NS

Household possessions index (0-10)

3.8

4.1

NS

(N)

(584)

(184)

NS = Not significant; $* *$ significant at $1 \%$ level; $*$ significant at $5 \%$ level; + significant at $10 \%$ level.

${ }^{a}$ Missing class rank included with bottom quartile. 
taken, however, because roughly 11 of the 36 schools had experienced no dropouts among the adolescents linked with those schools who fell into the sample (see Table 7). Differentiating statistically between these 11 schools was impossible in spite of their many differences according to the long list of school variables. Instead, a discrete-time hazard model of school dropout was created using logistic regression with the period of observation starting at the age of entry into school. The advantage of the discrete-time model over various continuous models is that it makes no assumption about the shape of the hazard-rate function.

Table 7 Distribution of the adolescent sample by school and district according to enrollment status, Kenya, 1996

\begin{tabular}{|c|c|c|c|c|c|c|}
\hline \multirow[b]{2}{*}{ School ID } & \multicolumn{2}{|c|}{ Kilifi } & \multicolumn{2}{|c|}{ Nakuru } & \multicolumn{2}{|c|}{ Nyeri } \\
\hline & $\begin{array}{c}\text { Number } \\
\text { ever } \\
\text { enrolled }\end{array}$ & $\begin{array}{c}\text { Number not } \\
\text { currently } \\
\text { enrolled }\end{array}$ & $\begin{array}{c}\text { Number } \\
\text { ever } \\
\text { enrolled }\end{array}$ & $\begin{array}{c}\text { Number not } \\
\text { currently } \\
\text { enrolled }\end{array}$ & $\begin{array}{c}\text { Number } \\
\text { ever } \\
\text { enrolled }\end{array}$ & $\begin{array}{c}\text { Number not } \\
\text { currently } \\
\text { enrolled }\end{array}$ \\
\hline 1 & 2 & 1 & 2 & - & 20 & - \\
\hline 2 & 26 & 7 & 19 & 4 & 7 & - \\
\hline 3 & 8 & 1 & 22 & 9 & 11 & 2 \\
\hline 4 & 10 & - & 20 & 2 & 11 & - \\
\hline 5 & 20 & 6 & 18 & 2 & 11 & 1 \\
\hline 6 & 15 & 6 & 12 & 2 & 9 & - \\
\hline 7 & 10 & 2 & 15 & 3 & 4 & - \\
\hline 8 & 49 & 5 & 33 & 8 & 18 & 1 \\
\hline 9 & 21 & 4 & 24 & 2 & 28 & 2 \\
\hline 10 & 18 & 5 & 18 & 2 & 7 & 1 \\
\hline 11 & na & na & 33 & - & 6 & - \\
\hline 12 & na & na & 18 & 2 & 38 & 5 \\
\hline 13 & na & na & 7 & 一 & 5 & - \\
\hline
\end{tabular}


Because the hazard of dropping out was expected to increase with age, a series of age dummy variables was included to allow the hazard of dropping out to vary by age. ${ }^{10}$

\section{RESULTS}

Given the small sample sizes and the authors' particular interest in gender differences, the number of variables that could be included in the statistical analysis was limited. In order to focus statistical attention on as many potentially interesting elements of school quality as possible, the analysis was undertaken in three steps. The first model estimates the familiar individual and family determinants of school dropout with controls for the three districts. ${ }^{11}$ Only those variables that were statistically significant in Model 1 were retained in the subsequent models. The second model includes an additional set of variables representing various elements of school quality as laid out in the conceptual framework shown in Table 1. By comparing the effects for boys and girls, we are able to see whether some school characteristics have different effects for boys and for girls. The third model, which includes only the 33 mixed schools in the sample, adds an additional set of school variables that differ by sex within mixed schools in order to explore whether gender differences within a school may have additional effects on the probability of dropout for boys and for girls. Although the effect of some of the covariates vary at different ages since school entrance, the adolescent sample is too small relative to the number of schools to support interaction terms. Thus, except in the case of school entry (see discussion below), interaction terms were not included.

The results for Model 1 are presented in Table 8 for all adolescents as well as for boys and for girls separately and includes, as indicated above, only those adolescents matched with a school. (Because of the small sample size, the level of significance given is less than usual, that is, $\mathrm{p}<0.10$ is noted, along with $\mathrm{p}<0.05$ and $\mathrm{p}<0.01$.) As we can see from column 1 , the dummy variables for being fe- 
Table 8 Model 1: Logistic regression model of dropping out of school, by individual and family characteristics only, all primary schools, Kenya, 1996

\begin{tabular}{|c|c|c|c|c|c|c|}
\hline \multirow[b]{2}{*}{ Variable } & \multicolumn{2}{|c|}{ Total } & \multicolumn{2}{|c|}{ Girls } & \multicolumn{2}{|c|}{ Boys } \\
\hline & $\begin{array}{l}\text { Odds } \\
\text { ratio }\end{array}$ & P-value & $\begin{array}{c}\text { Odds } \\
\text { ratio }\end{array}$ & P-value & $\begin{array}{c}\text { Odds } \\
\text { ratio }\end{array}$ & P-value \\
\hline \multicolumn{7}{|l|}{$\begin{array}{l}\text { Individual and family } \\
\text { characteristics }\end{array}$} \\
\hline Female $($ omitted $=$ male $)$ & $2.27 * *$ & 0.002 & & & & \\
\hline \multicolumn{7}{|l|}{ Age $($ omitted $=4-13)$} \\
\hline $14-16$ & $19.82 * *$ & 0.000 & $29.80 * *$ & 0.000 & $16.11 * *$ & 0.000 \\
\hline $17-19$ & $92.96 * *$ & 0.000 & $224.95 * *$ & 0.000 & $54.71 * *$ & 0.000 \\
\hline Entry age & $0.83^{*}$ & 0.036 & $0.79^{+}$ & 0.099 & 0.83 & 0.167 \\
\hline $\begin{array}{l}\text { Bottom quartile class rank }{ }^{\mathrm{a}} \\
\text { (omitted = top } 3 \text { quartiles) }\end{array}$ & 1.03 & 0.898 & 0.89 & 0.788 & 1.29 & 0.490 \\
\hline $\begin{array}{l}\text { Christian } \\
\text { (omitted = Muslim, other) }\end{array}$ & $0.21 * *$ & 0.000 & $0.21 * *$ & 0.001 & $0.18 * *$ & 0.002 \\
\hline $\begin{array}{l}\text { Kikuyu/Kalenjin } \\
\text { (omitted = other) }\end{array}$ & 1.21 & 0.799 & 0.64 & 0.737 & 1.39 & 0.647 \\
\hline \multicolumn{7}{|l|}{ District $($ omitted $=$ Kilifi) } \\
\hline Nakuru & 1.24 & 0.787 & 2.53 & 0.498 & 1.63 & 0.626 \\
\hline Nyeri & 0.29 & 0.175 & 0.50 & 0.650 & 0.40 & 0.422 \\
\hline \multicolumn{7}{|l|}{ Parents (omitted $=$ no) } \\
\hline Yes & $0.48^{*}$ & 0.034 & $0.29 *$ & 0.021 & 0.65 & 0.388 \\
\hline Missing & 0.44 & 0.312 & 0.45 & 0.401 & 0.46 & 0.465 \\
\hline \multicolumn{7}{|l|}{$\begin{array}{l}\text { Mother's education } \\
\text { (omitted = < primary) }\end{array}$} \\
\hline Primary completion & $0.53 *$ & 0.072 & $0.17 * *$ & 0.002 & 1.28 & 0.590 \\
\hline Secondary completion & 0.35 & 0.105 & 0.15 & 0.134 & 0.66 & 0.645 \\
\hline Missing & 1.28 & 0.486 & 0.56 & 0.315 & 2.13 & 0.121 \\
\hline $\begin{array}{l}\text { Female household head } \\
\text { (omitted = male head) }\end{array}$ & 0.64 & 0.157 & 0.50 & 0.166 & 0.69 & 0.385 \\
\hline $\begin{array}{l}\text { Number of same-mother } \\
\text { siblings }\end{array}$ & 1.00 & 0.980 & 1.11 & 0.123 & 0.92 & 0.347 \\
\hline $\begin{array}{l}\text { Household possessions index } \\
\text { (Scale } 0-10)\end{array}$ & 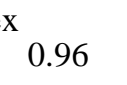 & 0.688 & 1.00 & 0.993 & 0.92 & 0.567 \\
\hline$(\mathrm{N})$ & $(5$ & 47) & $(258$ & & $(28$ & \\
\hline
\end{tabular}

** Significant at $1 \%$ level; $*$ significant at $5 \%$ level $;{ }^{+}$significant at $10 \%$ level.

${ }^{a}$ Missing class rank included with bottom quartile. 
male, for age and school entry age, for being Christian, for whether the adolescent's parents remain married to each other, and for mother's education, were all statistically significant and were, therefore, retained in the next two steps of the analysis. Surprisingly, neither the household possessions index nor the class rank (as a proportion of the total number of students in class in the previous or last school year) were important to the probability of dropping out. In both cases, measurement issues are a concern. Without a full-consumption module, ranking households in terms of permanent income is difficult. Furthermore, although the more highly-ranked students in a school would be expected to be less likely to drop out, the authors are not confident that adolescents were giving the interviewers truthful answers.

Sex, age, and mother's education have the effects expected. The odds of dropping out are twice as high for girls as for boys. The older the adolescent, the greater the probability of her or his dropping out. The higher the level of mother's education, the less likely an adolescent is to drop out, particularly in the case of girls. Being Christian reduces the odds of dropping out substantially, as does having parents that are married to each other (a proxy for the strength of parental support).

A new finding relates to the effect of age at school entry. Apparently, the older the adolescent at time of first school entry, controlling for age, the less the likelihood of her or his dropping out. ${ }^{12}$ For adolescents as a whole, each additional year of delay in school entry (a common phenomenon in Kenya and throughout Africa, where school entry continues up to the age of 10 and older (Lloyd and Blanc 1996) decreases the odds of dropping out by 17 percent for boys and girls combined and by 21 percent for girls (the coefficient for boys is not significant). Few data sets collect data on age of entry or full education histories that would allow age of entry to be calculated accurately, which data would be useful given the extent of repetition and temporary withdrawal throughout Africa. Thus, some 
of the time lost through late entry may be made up through delays in dropout. When the question of whether age of entry matters more at different ages of dropout was examined by including two interaction variables with the age dummies, the interactions were not significant, suggesting that full compensation does not occur (results not shown). Had the interactions been significant and the coefficients negative, the results would imply that later age at entry reduces the likelihood of dropping out during adolescence.

Although the authors would have preferred to include all the variables listed in Table 2 in the second model, multicollinearity and degrees of freedom constrained the model's design. Because of an interest in focusing attention on some of the less-studied aspects of school quality such as curriculum beyond the core; teachers' treatment of students; teachers' attitudes toward students' gender; school policies with gender implications; and the overall atmosphere of the school in terms of organization, rules, and student-to-student interactions; a small list of five core school-effectiveness variables was chosen that captures critical dimensions of time to learn (hours per week), material inputs (total fees, ${ }^{13}$ teachers' credentials, and in-service training), and pedagogical processes (only English spoken in class ${ }^{14}$ ). To this list, six variables were added from an extensive exploration of the data at a descriptive level, judged as to which were most solidly measured and most fully reflective of the school-quality dimension to be captured. This final list of six variables includes: (1) the number (out of a maximum of three-puberty, sexual biology, and STDs) of family life education subjects taught, to reflect curriculum beyond the core; (2) the proportion of students reporting the presence of someone at the school to whom they can turn for advice, to reflect the availability of supportive teachers or other counseling staff; (3) the proportion of observed classes starting on time and not interrupted, to reflect the overall level of orderliness of the school; (4) the number of "good" events in a standardized class, ${ }^{15}$ to reflect the quantity and quality of teacher-student inter- 
actions; (5) the proportion of teachers interviewed who say that math is "important" for girls to learn, to reflect the gender attitudes of teachers; and (6) whether the head teacher says a "severe" response should be given to teachers having sex with students, to reflect school policy on issues of sexual harassment.

Table 9 presents the results of the second model, which adds the 11 schoolquality variables discussed above-and which represents each of the major elements enumerated in the school-quality framework as presented in Table 1-to the six individual family variables that had been significant in Model 1 . The results are not presented for the pooled sample here, because, as Table 8 indicated, striking differences by sex are found. With two exceptions, the coefficients for personal and family characteristics retain their signs and significance for both sexes. Once school characteristics are controlled, age of entry no longer has a statistically significant effect on girls' dropout rates, further evidence that girls who start school late end with fewer years of schooling than those who begin school earlier. Also, one category of mother's education, secondary completion, is found significant for girls.

Because of the way the school variables have been defined, the odds ratios should be universally below one. In other words, as each element becomes more positive in terms of "quality," the odds of dropping out should decline. When compared with a model with only the statistically significant individual and family variables from Model 1 , these 11 variables add significantly to the fit of the model for boys alone. The log-likelihood test for the addition of the school variables indicates they are jointly significant at $p=0.020$. The school variables, however, do not appear to add to the explanatory power of the model for girls $(\mathrm{p}$ $=0.524)$. Indeed, no school variables are statistically significant, even at the 10 percent level, in the girls-only regression. On the other hand, the probability of dropout for boys appears to be reduced (in a statistically significant fashion) in schools with greater resources (as measured by fees) and in those where more 
Table 9 Model 2: Logistic regression model of dropping out of school, by individual, family, and school characteristics, for all sample schools, Kenya, 1996

\begin{tabular}{|c|c|c|c|c|}
\hline \multirow[b]{2}{*}{ Variable } & \multicolumn{2}{|c|}{ Girls } & \multicolumn{2}{|c|}{ Boys } \\
\hline & $\begin{array}{l}\text { Odds } \\
\text { ratio }\end{array}$ & P-value & $\begin{array}{c}\text { Odds } \\
\text { ratio }\end{array}$ & P-value \\
\hline \multicolumn{5}{|l|}{ Individual and family characteristics } \\
\hline \multicolumn{5}{|l|}{ Female $($ omitted $=$ male $)$} \\
\hline \multicolumn{5}{|l|}{ Age $($ omitted $=4-13)$} \\
\hline $14-16$ & $23.00 * *$ & 0.000 & $14.92 * *$ & 0.000 \\
\hline $17-19$ & $157.40 * *$ & 0.000 & $57.72 * *$ & 0.000 \\
\hline Entry age & 0.86 & 0.226 & 0.96 & 0.687 \\
\hline Christian (omitted = Muslim, other) & $0.19 * *$ & 0.000 & $0.14 * *$ & 0.000 \\
\hline \multicolumn{5}{|l|}{ Parents married (omitted $=$ no) } \\
\hline Yes & $0.33 *$ & 0.011 & 0.53 & 0.104 \\
\hline Missing & 0.19 & 0.263 & 0.48 & 0.393 \\
\hline \multicolumn{5}{|l|}{ Mother's education (omitted $=<$ primary) } \\
\hline Primary completion & $0.22 * *$ & 0.000 & 1.08 & 0.868 \\
\hline Secondary completion & $0.06^{*}$ & 0.027 & 0.57 & 0.511 \\
\hline Missing & 0.55 & 0.259 & 1.74 & 0.342 \\
\hline \multicolumn{5}{|l|}{ School characteristics } \\
\hline \multicolumn{5}{|l|}{ Head teacher } \\
\hline Daily school hours & 0.92 & 0.439 & 0.92 & 0.528 \\
\hline Total school fees $(100 \mathrm{KSh})^{\mathrm{a}}$ & 0.99 & 0.516 & $0.97^{+}$ & 0.076 \\
\hline $\begin{array}{l}\text { Teachers' credentials (\% with at } \\
\text { least KCSE) }{ }^{\mathrm{b}, \mathrm{c}}\end{array}$ & 1.07 & 0.698 & 0.96 & 0.859 \\
\hline $\begin{array}{l}\text { Number of family life education } \\
\text { subjects taught }(0-3)\end{array}$ & 1.00 & 0.995 & 0.76 & 0.321 \\
\hline $\begin{array}{l}\text { Response to teacher-student sex } \\
(1=\text { severe })\end{array}$ & 1.06 & 0.910 & 0.52 & 0.180 \\
\hline \multicolumn{5}{|l|}{ Teachers (standards 7/8, math/English) } \\
\hline In-service training ( $\%$ in 2 years $)^{c}$ & 1.03 & 0.833 & 1.19 & 0.161 \\
\hline Math important for girls $(\%)^{\mathrm{c}}$ & 0.87 & 0.142 & 0.90 & 0.454 \\
\hline \multicolumn{5}{|l|}{ Observed classes (standards 7/8; math/English) } \\
\hline On time/not interrupted $(\%)^{\mathrm{c}}$ & 1.04 & 0.665 & 1.21 & 0.195 \\
\hline Only English spoken $(\%)^{\mathrm{c}}$ & 1.07 & 0.320 & 0.96 & 0.681 \\
\hline $\begin{array}{l}\text { Average number of "good" events } \\
\text { (standardized) }\end{array}$ & 1.01 & 0.499 & 1.00 & 0.729 \\
\hline \multicolumn{5}{|l|}{ Students } \\
\hline Presence of advisor $(\%)^{\mathrm{c}}$ & 0.73 & 0.153 & $0.58^{+}$ & 0.052 \\
\hline$(\mathrm{N})$ & \multicolumn{2}{|c|}{$(275)$} & \multicolumn{2}{|c|}{$(301)$} \\
\hline \multicolumn{5}{|l|}{ Significance level of log-likelihood test for } \\
\hline
\end{tabular}

** Significant at $1 \%$ level; * significant at $5 \%$ level; ${ }^{+}$significant at $10 \%$ level.

${ }^{\mathrm{a}} 100 \mathrm{KSh}=$ approximately US $\$ 2$. ${ }^{\mathrm{b}} \mathrm{KCSE}=$ Kenyan Certificate of Secondary Education. ${ }^{\mathrm{c}}$ The odds ratio assumes an increment of ten percentage points in the independent variable. 
students say that someone is available in the school from whom they can seek advice. Although we would expect factors such as the gender attitudes of teachers and the presence of staff who can provide advice to be particularly important to girls, these effects, while found to be in the right direction, are not statistically significant (possibly because of the small sample sizes-more boys than girls are in the sample).

From this analysis, we might be forced to conclude that school quality does not matter to girls. However, from the authors' earlier work describing the experiences of adolescents (Mensch and Lloyd [1998]), we know that the primary school environment in Kenya is a harsh one for both sexes and that girls suffer in particular from negative attitudes and discriminatory behavior in all types of schools. Although these measured elements of school quality may matter to the quality of the daily lives of girls, these regression results show that they appear to make little difference to whether they drop out of school in this relatively small sample; instead family factors seem of overriding importance. By contrast, family characteristics are less important for boys (in particular, parents' marital status and mother's education), suggesting that the universal commitment on the part of Kenyan parents to further schooling for boys apparently leaves more room for the quality of the school to have an effect on a boy's number of years at school than on a girl's.

Model 2 tests only whether certain school characteristics have differential effects on retention of boys and girls in school. However, exploring whether differences in gender treatment or perceptions might be important is also of interest. To explore these questions, however, we are restricted to studying mixed schools. The sample of primary schools included three single-sex school in Nakuru-one all-girls day school, one all-girls boarding school, and one all-boys school (day and boarding). Twenty-eight adolescents in our sample attended these schools, and they are indeed a selective group. They come from households with socioeconomic advantages, have parents with more education, and started school at a 
younger age than those in the mixed schools. Furthermore, they are all Christian and belong to one of the dominant ethnic groups in the district (Kikuyu or Kalenjin). To explore the issue of differential gender treatment, however, we are constrained to use this slightly more selective sample. Nearly identical results were obtained when Model 2 was run for mixed schools only (results not shown).

In Model 3, six variables are added to capture some of the gender differences in students' treatment in mixed schools. It is probably not just the aggregate effect of particular school factors that matter but also the disparity between boys and girls in the level of certain factors. Three completely new variables are included that were not measurable in single-sex schools: (1) the proportion of students who think boys and girls are treated equally in the school; (2) an index of the overall level of harassment between boys and girls reported by students (measured as the average proportion of responses to eight possible questions on harassment that were asked of students for which they did not report its occurrence); and (3) the difference in harassment of girls by boys and harassment of boys by girls. Three additional variables assess differences between boys and girls in previously measured dimensions of school quality. These include boy/girl differences in the number of "good" events observed in a standardized class; the difference between boys and girls in the proportion reporting the presence of someone in the school from whom they could seek advice, and the difference between boys and girls in the proportion reporting that boys and girls are treated equally. Each of the difference variables is set up in such a way that an increase in its value should increase the likelihood of girls' dropping out. Other possible boy-girl differences were not included in the analysis because the correlation between the relevant school characteristic for boys and the analogous school characteristic for girls was more than 0.7 .

We can see from Table 10 that the addition of this fuller set of school variables to the statistically significant individual and family variables from Table 8 significantly improves the fit of the model for both girls and boys at the 10 per- 
Table 10 Model 3: Logistic regression model of dropping out of school: Individual, family, and school characteristics and gender differences in school characteristics (mixed schools only)

\begin{tabular}{|c|c|c|c|c|}
\hline \multirow[b]{2}{*}{ Variable } & \multicolumn{2}{|c|}{ Girls } & \multicolumn{2}{|c|}{ Boys } \\
\hline & $\begin{array}{l}\text { Odds } \\
\text { ratio }\end{array}$ & P-value & $\begin{array}{l}\text { Odds } \\
\text { ratio }\end{array}$ & P-value \\
\hline \multicolumn{5}{|l|}{ Individual and family characteristics } \\
\hline \multicolumn{5}{|l|}{ Female $($ omitted $=$ male $)$} \\
\hline \multicolumn{5}{|l|}{ Age (omitted $=4-13$ ) } \\
\hline $14-16$ & $24.57 * *$ & 0.000 & $14.12 * *$ & 0.000 \\
\hline $17-19$ & $245.65^{* *}$ & 0.000 & $77.23 * *$ & 0.000 \\
\hline Entry age & $0.77^{+}$ & 0.053 & 0.96 & 0.751 \\
\hline Christian (omitted = Muslim, other) & $0.13 * *$ & 0.000 & $0.13 * *$ & 0.000 \\
\hline \multicolumn{5}{|l|}{ Parents married (omitted $=$ no) } \\
\hline Yes & $0.41^{+}$ & 0.067 & $0.40 *$ & 0.030 \\
\hline Missing & 0.48 & 0.517 & 0.52 & 0.363 \\
\hline \multicolumn{5}{|l|}{ Mother's education (omitted $=<$ primary) } \\
\hline Primary completion & $0.30 *$ & 0.016 & 0.96 & 0.939 \\
\hline Secondary completion & $0.10^{+}$ & 0.088 & 0.74 & 0.729 \\
\hline Missing & 0.53 & 0.270 & 2.32 & 0.216 \\
\hline \multicolumn{5}{|l|}{ School characteristic } \\
\hline \multicolumn{5}{|l|}{ Head teacher } \\
\hline Daily school hours & 0.69 & 0.118 & 0.84 & 0.318 \\
\hline Total school fees $(100 \mathrm{KSh})^{\mathrm{a}}$ & $0.94 *$ & 0.040 & 0.98 & 0.340 \\
\hline Teacher credentials ( $\%$ with at least KCSE) $)^{\mathrm{b}, \mathrm{c}}$ & c $\quad 1.77$ & 0.137 & 0.78 & 0.410 \\
\hline $\begin{array}{l}\text { Number of family life education } \\
\text { subjects taught }(0-3)\end{array}$ & 1.46 & 0.500 & 0.61 & 0.147 \\
\hline $\begin{array}{l}\text { Response to teacher-student sex } \\
(1=\text { severe })\end{array}$ & 3.02 & 0.238 & 0.46 & 0.168 \\
\hline \multicolumn{5}{|l|}{ Teachers (standards 7/8, math/English) } \\
\hline In-service training ( $\%$ in 2 years $)^{b}$ & $0.60 *$ & 0.013 & 1.08 & 0.729 \\
\hline Math important for girls $(\%)^{\mathrm{b}}$ & $0.59 *$ & 0.010 & 0.92 & 0.628 \\
\hline \multicolumn{5}{|l|}{ Observed classes (standard 7/8; math/English) } \\
\hline On time/not interrupted $(\%)^{\mathrm{b}}$ & 0.82 & 0.404 & 1.34 & 0.132 \\
\hline Only English spoken $(\%)^{\mathrm{b}}$ & 1.19 & 0.343 & 0.89 & 0.365 \\
\hline $\begin{array}{l}\text { Average number of "good" events } \\
\text { (standardized) }\end{array}$ & 1.02 & 0.442 & 0.97 & 0.301 \\
\hline $\begin{array}{l}\text { Average number of "good" events } \\
\text { (boy/girl difference) }\end{array}$ & $1.39^{+}$ & 0.072 & 1.13 & 0.340 \\
\hline
\end{tabular}


Table 10 (continued)

\begin{tabular}{|c|c|c|c|c|}
\hline \multirow[b]{2}{*}{ Variable } & \multicolumn{2}{|c|}{ Girls } & \multicolumn{2}{|c|}{ Boys } \\
\hline & $\begin{array}{c}\text { Odds } \\
\text { ratio }\end{array}$ & P-value & $\begin{array}{c}\text { Odds } \\
\text { ratio }\end{array}$ & P-value \\
\hline \multicolumn{5}{|l|}{ Students } \\
\hline Presence of advisor $(\%)^{\mathrm{b}}$ & 0.42 & 0.297 & 0.78 & 0.574 \\
\hline Presence of advisor (boy/girl difference) & $1.46^{*}$ & 0.039 & 0.98 & 0.906 \\
\hline Equal gender treatment $(\%)$ & 1.44 & 0.612 & 0.57 & 0.238 \\
\hline Equal gender treatment (boy/girl difference) & $2.03 * *$ & 0.004 & 0.98 & 0.899 \\
\hline Harassment ( $\%$ of possible occurrences) & 1.09 & 0.809 & 1.29 & 0.484 \\
\hline Harassment (boy/girl difference) & $2.61 *$ & 0.019 & 0.84 & 0.692 \\
\hline$(\mathrm{N})$ & \multicolumn{2}{|c|}{$(264)$} & \multicolumn{2}{|c|}{$(283)$} \\
\hline $\begin{array}{l}\text { Significance level of log-likelihood test for } \\
\text { model adding school characteristics as a block }\end{array}$ & \multicolumn{2}{|c|}{0.073} & \multicolumn{2}{|c|}{0.059} \\
\hline
\end{tabular}

** Significant at $1 \%$ level; * significant at $5 \%$ level; ${ }^{+}$significant at $10 \%$ level.

${ }^{\mathrm{a}} 100 \mathrm{KSh}=$ approximately US $\$ 2$. ${ }^{\mathrm{b}}$ The odds ratio assumes an increment of ten percentage points in the independent variable. ${ }^{\mathrm{C}} \mathrm{KCSE}=$ Kenyan Certificate of Secondary Education.

cent level ( $p=0.073$ for girls and $p=0.059$ for boys). More of the individual school coefficients become significant for girls, and all are in the hypothesized direction. No school variables are significant for boys. Among the basic set of school variables from Model 2, we find significant effects of total fees, teacher training, and the importance of math for girls on the probability of dropout for girls. Each addition of 100 shillings to the per-student budget for material resources reduces the odds of a girl's dropping out by 6 percent. For each 10 percent increment in the proportion of the math and English teachers from standards 7 and 8 with in-service training in the last two years, the odds for a girl's dropping out decline by 40 percent. With each 10 percent increment in the number of teachers who say that studying math is "important" for girls, the chance of girls' dropping out decreases by 41 percent. The effect of this gender-preference variable had been smaller and not significant in Model 2. Age at entry again becomes significant for girls, as it was in Model 1 . The interaction variables of age at entry 
with age are again insignificant, however, suggesting that the time lost in school due to late entry is not fully made up by delayed time to dropout (results not shown).

The four variables for boy/girl difference are significant for girls and in the hypothesized direction. Each time the boy/girl difference in the number of "good" events observed in class increases by 1 , a 39 percent increase occurs in the odds that a girl will drop out. With each 10-percentage-point difference between boys and girls in the proportion reporting that they can seek advice from someone on the school staff, there is a 46 percent increase in the probability of girls' dropping out. With each 10-percentage-point difference between boys and girls in the extent to which they report that boys and girls are treated equally, there is a 103 percent increase in the probability that a girl will drop out. Finally, the greater the difference between the harassment of girls by boys and the harassment of boys by girls, the greater the chance of girls' dropping out. In each case, the overall level of the variable has been controlled for, but its effect, once the boy/girl difference is added, is not significant for girls. From these results, we conclude that school environments are discouraging to girls where boys are favored in class and provided with a more supportive environment in terms of advice, where teachers take the importance of more difficult subjects like math less seriously for girls than for boys, where boys are left free to harass girls, and where girls' experience of less equal treatment is not fully recognized by boys. ${ }^{16}$ No analogous effects are found for boys.

Differences by gender in direction of the effects of variables measuring the extensiveness of the family life education curriculum and the strictness of the head teacher with respect to teacher-student sex are puzzling at first glance. Although not statistically significant, the results of these two variables for girls would suggest that the teaching of family life education subjects and the enforcement of strict rules about teacher-student sex are unfavorable to girls and lead to a greater likelihood of their dropping out. An endogeneity problem may have 
arisen here in that the very schools that see schoolgirl pregnancy as a problem because more girls drop out are more supportive of family life education and stricter in their policies in response to teacher-student sex. Endogeneity is less like to be operating in the case of boys because boys are rarely forced to leave school under similar circumstances. Therefore, we might interpret the effects for boys as more likely to be meaningful. If so, this is good news; the implication is that schools that provide family life education subjects with real content in terms of information on puberty, sexual biology, and STDs, and that set strict standards on sexual conduct at school (as defined by whether teachers feel that the school response to a teacher who had sex with a student should be "severe") have better retention rates.

\section{CONCLUSION}

The goal in this paper has been an ambitious one. It is the authors' hypothesis that there is more to school effectiveness than the development of academic competency, and there is more to the "quality" of the school environment than time to learn, material resources for the basic curriculum, and pedagogical practices. To an already complex set of issues, the authors feel that introducing the consideration of various elements of schools that are either different for girls and boys or that have a potentially different effect for boys than for girls is important. Indeed, for those with a particular interest in the demography of schooling, these issues are potentially of vital importance as we seek to find appropriate policies that will support girls to continue beyond the primary level where so many of the documented social returns to education become salient.

The first finding with potential policy significance relates to the age of school entry. The results indicate that girls who start late are disadvantaged in terms of school attainment. Educating parents about the value of starting their children's education early is important. However, policies that do not allow entry after the normal starting age cannot be recommended, because they may put girls 
at a disadvantage. For example, one of the reasons Kenya has achieved universal enrollment rates is because of its flexible policy about age at entry. By contrast, in Egypt, where policies are rigid, more than 10 percent of girls never attend school (Montgomery and Lloyd 1998).

The results also document both the ongoing power of existing gender systems at the level of the family and the potential power of gender systems within the school environment in affecting the educational attainment of girls. The determination as to whether a girl will remain in school from year to year remains largely in the hands of her family. The school can weigh in on the issue of girls' retention, however. The presence of parent-teacher associations in so many schools provides the opportunity for an important vehicle for transmitting messages to families about the importance of schooling for girls. To the extent that school factors matter for girls in affecting the timing of dropout, gender aspects of the school environment appear to be particularly salient. Variables measuring gender differences in treatment were universally statistically significant for girls and in the hypothesized direction. Schools that discriminate in favor of boys or against girls have higher dropout rates for girls.

Although the results of this study must be seen as tentative and exploratory because the size of the sample and the limitations of cross-sectional analysis, they are sufficiently suggestive to encourage further research in this area. The potential for schools to make a difference in the lives of young people should be expected to grow steadily along with the spread of mass schooling in developing countries; thus the opportunity costs associated with schools of poor quality become ever greater with each passing year. 


\section{Notes}

1. See Fuller and Clarke 1994; Harbison and Hanushek 1992; Lockheed and Verspoor et al. 1991; Fuller 1987; Heyneman and Loxley 1983 for reviews of a large and growing empirical literature.

2. Choice of the specific primary schools to be visited was based on the goal of a minimum of 60 percent coverage of the schoolgoing adolescents in each cluster.

3. Appleton (1995) looked at the effect of teachers' attitudes toward the aptitudes or "teachability" of boys and girls, but did not explore other aspects of the school environment that might be different for the two sexes.

4. Virtually all respondents of both sexes (over 99 percent) in Nakuru and Nyeri have been to school. In Kilifi, 96 percent of boys and 89 percent of girls have ever been to school (Ajayi et al. 1997).

5. In each school, the researchers visited and observed eight classes of standards 7 and 8-four math classes and four English classes, two classes for each teacher interviewed. Their job was to mark down each interaction between a student and teacher and to determine its nature. The goal was to assess whether teachers pay more attention to boys than to girls and provide boys with more encouragement or whether they treat girls and boys equally. In constructing variables ot measure "good" interactions, the attempt was made to include all events recorded by our observers that had a postitive or supportive tone-or at least those that did not have a negative one. Thus, instances were included of students reading aloud; students' making presentations in front of the class; teachers instructing or explain- 
ing; teachers acknowledging, extending, amplifying or praising correct answers; teachers completing, explaining, or seeking responses to students' questions; and teachers positively acknowledging expanding upon, or encouraging students' comments. We base this procedure on the earlier work of Sadker and Sadker (1995) in US classrooms.

6. The metric differs between the teacher and head teacher form of this variable in Table 2 because there is only one head teacher per school.

7. Of the 754 adolescents in the sample who had ever been to school, $189 \mathrm{did}$ not provide an age at entry into school. For these adolescents, the authors were able to estimate the age at entry from other information provided. Taking as the base age either current age for those still in school or the age at school leaving for those no longer in school, age of entry was calculated as the base age minus (1) the number of standards reached by the adolescent, (2) the number of standards repeated by the adolescent, and (3) the number of years the adolescent stated that he or she temporarily withdrew from school. One year was added back into the resulting age for those students still in school who had not had their birthdays at the time of the survey. Testing this approach on those students who did list valid school starting ages, we determined that the formula yielded estimates to within one year of the reported age in 92 percent of the cases.

8. Because the Kenyan national sampling frome was relatively old at the time of the survey, a lot of variability occurred in the size of the clusters considered, demonstrating the mobility of the Kenyan population.

9. The household possessions index ranges in value from 0-10. Each household's score is calculated by adding a value of " 1 " to the index for 
the possession of each of the following items: a metal or tile roof; five minutes' distance or less from a water source; an improved pit/flush toilet; a radio; a television; at least one sleeping room for every two people in the household; a bicycle; ownership of land; ownership of livestock; and ownership of a market stall or shop.

10. From the particular peculiarities of the sample, in which only two-thirds of the schools contained adolescents from the sample who had dropped out, the precision of the estimates will be compromised by a high degree of statistical noise. The Huber correction was applied to adjust the standard errors for cross-observation correlation due to the unmeasured differences across adolescents. Within the limitations of STATA, the statistical packaged used for estimation, correcting standard errors for measurements being available from only 36 schools, applied to 583 individuals, was not possible at the same time. A model with the Huber correction defining the school as the single grouping variable was also run, and results were found similar to those presented in Tables 8-10.

11. Although many researchers include a marital-status variable, few have access to information about whether a child's parents are still married to each other. This variable is important because it may reflect the extent of support and commitment to that child's education.

12. Schultz (1998), in his commments to the authors, pointed out that age of entry is potentially endogenous in that some of the same factors affecting parents' decisions about how long a child should stay in school also affect decisions about timing of first entry. The models were run both with and without age at entry; the absence of the age of entry variable had no impact on any of the estimated effects. 
13. Total feees were chosen as a proxy for all material inputs beyond the teaching staff because the Ministry of Education pays teachers' salaries; total school fees cover all other expenses incurred by attending the school.

14. If English is spoken in class, school quality is assumed to be better than if it is not because the primary school leaving exams are given in English. Therefore, students who are taught in English are presumably better prepared for these exams. If teachers do not speak English fluently, however, the quality of instruction may suffer.

15. Because the duration of classes and the composition of classes by sex vary, we adjusted the number of good events to a "standard" class of 40 minutes in duration with 20 students of each sex.

16. In a fragile model, with relatively few degrees on freedom, these findings might reflect the accident of a particular specification. However, they were found to be robust to a series of alternate specifications.

\section{References}

Ajayi, Ayorinde et al. 1997. Schooling and the Experience of Adolescents in Kenya. Nairobi: Population Council.

Appleton, Simon. 1995. Exam Determinants in Kenyan Primary School: Determinants and Gender Differences. Washington, DC: McNamara Fellowships Program, Economic Development Institute of the World Bank.

Behrman, Jere R. and Nancy Birdsall. 1983. "The quality of schooling: Quantity alone is misleading," The American Economic Review 73, no. 5: 928-946.

Bommier, Antoine and Sylvie Lambert. 1997. "Educational demand and age of school enrollment in Tanzania." Paper presented at the Annual Meet- 
ing of the Population Association of America, 27-29 March, Washington, DC.

Chernichovsky, Dov. 1985. "Socioeconomic and demographic aspects of school enrollment and attendance in rural Botswana," Economic Development and Cultural Change 33, no. 2: 319-332.

Fuller, Bruce. 1987. "What factors raise achievement in the third world?" Review of Educational Research 57: 255-292.

Fuller, Bruce and Prema Clarke 1994. "Raising school effects while ignoring culture? Local conditions and the influence of classroom tools, rules, and pedagogy," Review of Educational Research 64, no. 1: 119-157.

Fuller, Bruce, Haiyan Hua, and Conrad W. Snyder, Jr. 1994. "When girls learn more than boys: The influence of time in school and pedagogy in Botswana," Comparative Education Review 38, no. 3: 347-376.

Fuller, Bruce and Conrad W. Snyder, Jr. 1991. "Vocal teachers, silent pupils? Life in Botswana classrooms," Comparative Education Review 35, no. 2: 274-294.

Glewwe, Paul and Hanan Jacoby. 1994. "Student achievement and schooling choice in low income countries," The Journal of Human Resources 29, no. 3: 843-864.

Glewwe, Paul, Margaret E. Grosh, Hanan Jacoby, and Marlaine E. Lockheed. 1995. "An eclectic approach to estimating the determinants of achievement in Jamaican primary education," The World Bank Economic Review 9, no. 2: 231-258.

Hanushek, Eric A. and Victor Lavy. 1994. "School quality, achievement bias, and dropout behavior in Egypt." World Bank Living Standards Measurement Study Working Paper 107. Washington, DC.

Harbison, Ralph W. and Eric A. Hanushek. 1992. Educational Performance of the Poor: Lessons from Rural Northeast Brazil. New York: Oxford University Press. 
Heyneman, Stephen P. and William A. Loxley. 1983. "The effect of primaryschool quality on academic achievement across twenty-nine high- and lowincome countries," American Journal of Sociology 88, no. 6: 1162-1194.

Hill, M. Anne and Elizabeth M. King. 1993. "Women's education in developing countries: An overview," in Elizabeth M. King and M. Anne Hill (eds.), Women's Education in Developing Countries: Barriers, Benefits and Policies. Baltimore: Johns Hopkins University Press. Pp. 1-50.

Jamison, Dean T. and Marlaine E. Lockheed. 1987. "Participation in schooling: Determinants and learning outcomes in Nepal," Economic Development and Cultural Change 35, no. 2: 279-306.

Khandker, Shahidur R., Victor Lavy, and Deon Filmer. 1994. "Schooling and cognitive achievements of children in Morocco: Can the government improve outcomes?" World Bank Discussion Papers No. 264. Washington, DC.

Lee, Jong Wha and Robert J. Barro. 1997. "Schooling quality in a cross section of countries," National Bureau of Economic Research Working Paper No. 6198. Cambridge, MA.

Lockheed, Marlaine E. and Nicholas T. Longford. 1989. "A multilevel model of school effectiveness in a developing country," World Bank Discussion Papers No. 69. Washington, DC.

Lockheed, Marlaine E. and Adriaan M. Verspoor et al. 1991. Improving Primary Education in Developing Countries. Oxford: Oxford University Press.

Lloyd, Cynthia B. and Anastasia J. Gage-Brandon. 1994. "High fertility and children's schooling in Ghana: Sex differences in parental contributions and educational outcomes," Population Studies 48, no. 2: 293-306.

Lloyd, Cynthia B. and Ann K. Blanc. 1996. "Children's schooling in sub-Saharan Africa: The role of fathers, mothers, and others," Population and Development Review 22, no. 2: 265-298. 
Lloyd, Cynthia B. and Barbara S. Mensch. 1998. "Implications of formal schooling for girls' transitions to adulthood in developing countries," in Caroline Bledsoe, John B. Casterline, Jennifer A. Johnson-Kuhn, and John G. Haaga (eds.), Critical Perspectives on Schooling and Fertility in the Developing World. Washington, DC: National Academy Press, forthcoming.

Mensch, Barbara S. and Cynthia B. Lloyd. 1997. "Gender differences in the schooling experiences of adolescents in low-income countries: The case of Kenya." Policy Research Division Working Paper No. 95. New York: Population Council.

- 1998. "Gender differences in the schooling experiences of adolescents in low-income countries: The case of Kenya," Studies in Family Planning 29, no. 2: 167-184.

Montgomery, Mark R. and Cynthia B. Lloyd. 1998. "Excess fertility, unintended births, and children's schooling," in Caroline Bledsoe, John B. Casterline, Jennifer A. Johnson-Kuhn, and John G. Haaga (eds.), Critical Perspectives on Schooling and Fertility in the Developing World. Washington, DC: National Academy Press, forthcoming.

Sadker, Myra and David Sadker. 1995. Failing at Fairness: How Our Schools Cheat Girls. New York: Simon \& Schuster.

Sathar, Zeba and Cynthia B. Lloyd. 1994. "Who gets primary schooling in Pakistan: Inequalities among and within families," Pakistan Development Review 33, no. 2: 103-134.

Schultz, T. Paul. 1998. Personal communication.

Sen, Amartya. 1997. "Editorial: Human capital and human capability," World Development 25, no. 2: 1959-1961.

Tan, Jee-Peng, Julia Lane, and Paul Coustere. 1997. "Putting inputs to work in elementary schools: What can be done in the Philippines?" Economic Development and Cultural Change 45, no. 4: 857-881. 


\title{
POLICY RESEARCH DIVISION WORKING PAPERS
}

\author{
Recent Back Issues
}

1996

*83 Sajeda Amin, Ian Diamond, and Fiona Steele, "Contraception and religious practice in Bangladesh."

84 John B. Casterline, Aurora E. Perez, and Ann E. Biddlecom, "Factors underlying unmet need for family planning in the Philippines."

85 Geoffrey McNicoll, "Governance of fertility transition: Regularity and duress."

*86 John Bongaarts, "Population pressure and the food supply system in the developing world."

87 Sajeda Amin, "Family structure and change in rural Bangladesh."

*88 John Bongaarts and Susan Cotts Watkins, "Social interactions and contemporary fertility transitions."
*89 Cynthia B. Lloyd and Mark R. Montgomery, "The consequences of unintended fertility for investments in children: Conceptual and methodological issues."

* 90 Zeba Sathar and Sonalde Desai, "Work patterns in rural Pakistan: Intersections between gender, family, and class."

*91 Mark R. Montgomery, "Learning and lags in mortality perceptions."

92 Ann E. Biddlecom, John B. Casterline, and Aurora E. Perez, "Men's and women's views of contraception."
93 James F. Phillips, Fred N. Binka, Martin Adjuik, Alex Nazzar, and Kubaze Frank Adazu, "The determinants of contraceptive innovation: A case-control study of family planning acceptance in a traditional African society."
94 John Bongaarts and Sajeda Amin, "Prospects for fertility decline and implications for population growth in South Asia."

95 Barbara S. Mensch and Cynthia B. Lloyd, "Gender differences in the

* No longer available 
schooling experiences of adolescents in low-income countries: The case of Kenya."

96 Martin Brockerhoff and Ellen Brennan, "The poverty of cities in the developing world."

97 Carol E. Kaufman, "Reproductive control in South Africa."

98 John Bongaarts, "Trends in unwanted childbearing in the developing world."

99 Mary Arends-Kuenning, "How do family planning workers' visits affect women's contraceptive behavior in Bangladesh?"

100 Mark R. Montgomery and Cynthia B. Lloyd, "Excess fertility, unintended births, and children's schooling."
101 Mary Arends-Kuenning, “The equity and efficiency of doorstep delivery of contraceptives in Bangladesh."

102 Sajeda Amin, Ian Diamond, Ruchira T. Naved, and Margaret Newby, "Transition to adulthood of female factory workers: Some evidence from Bangladesh."

*103 Margaret E. Greene and Ann E. Biddlecom, "Absent and problematic men: Demographic accounts of male reproductive roles."

104 Michael P. Todaro, "Urbanization, unemployment, and migration in Africa: Theory and policy."

105 Geoffrey McNicoll, "Population and poverty: A review and restatement."
106 Sajeda Amin and Gilda Sedgh, "Incentive schemes for school attendance in rural Bangladesh."

107 Martin Brockerhoff and Paul Hewett, "Ethnicity and child mortality in subSaharan Africa."

108 Ann E. Biddlecom and Bolaji M. Fapohunda, "Covert contraceptive use: Prevalence, motivations, and consequences."

109 John Bongaarts and Griffith Feeney, "On the quantum and tempo of fertility."
110 Barbara S. Mensch, Daniel Bagah, Wesley H. Clark, and Fred Binka, "The changing social environment for adolescents in the Kassena-Nankana District of northern Ghana: Implications for reproductive behavior."

111 Martin Brockerhoff and Ann Biddlecom, "Migration, sexual behavior, and HIV diffusion in Kenya."

112 Zeba A. Sathar and John B. Casterline, "The onset of fertility transition in Pakistan." 
113 Geoffrey McNicoll, "Government and fertility in transitional and post-transitional societies."

114 John Bongaarts, "Fertility and reproductive preferences in post-transitional societies."

115 Fiona Steele, Sajeda Amin, and Ruchira T. Naved, "The impact of an integrated micro-credit program on women's empowerment and fertility behavior in rural Bangladesh."

116 Cynthia B. Lloyd, Barbara S. Mensch, and Wesley H. Clark, "The effects of primary school quality on the educational participation and attainment of Kenyan girls and boys." 